\title{
Article
}

\section{Digital Trading Applications and Bank Performance: Evidence from Russia}

\author{
Anton Lisin ${ }^{1}$, Kristina Shvandar ${ }^{2}$, Artur Meynkhard ${ }^{1} \mathbb{D}$, Mafura Uandykova ${ }^{3}$, Serhat Yuksel ${ }^{4, *}$, \\ Konstantin Kalmikov ${ }^{5}$, Oleg Litvishko ${ }^{5}$ and Xenia Tabachkova ${ }^{1}$
}

1 Financial Faculty, Financial University under the Government of the Russian Federation, 125993 Moscow, Russia; mrfoxv@list.ru (A.L.); meynkhard@yandex.ru (A.M.); xtabachkova@yandex.ru (X.T.)

2 Financial Research Institute of Ministry of Finance of the Russian Federation, 127006 Moscow, Russia; kristinashvandar@ya.ru

3 Department of Digital Engineering and Data Analysis, Narxoz University, Almaty 050035, Kazakhstan; Mafura.Uandykova@ya.ru

4 School of Business, Istanbul Medipol University, Istanbul 34083, Turkey

5 Department of Financial Management, Plekhanov Russian University of Economics, 117997 Moscow, Russia; kalmikova989@ya.ru (K.K.); oleh.litvishko@ya.ru (O.L.)

* Correspondence: yukselserh@ya.ru

check for updates

Citation: Lisin, A.; Shvandar, K.; Meynkhard, A.; Uandykova, M.; Yuksel, S.; Kalmikov, K.; Litvishko, O.; Tabachkova, X. Digital Trading Applications and Bank Performance: Evidence from Russia. J. Open Innov. Technol. Mark. Complex. 2021, 7, 194. https: / / doi.org/10.3390/ joitmc7030194

Received: 24 June 2021

Accepted: 18 August 2021

Published: 1 September 2021

Publisher's Note: MDPI stays neutral with regard to jurisdictional claims in published maps and institutional affiliations.

Copyright: (C) 2021 by the authors. Licensee MDPI, Basel, Switzerland. This article is an open access article distributed under the terms and conditions of the Creative Commons Attribution (CC BY) license (https:/ / creativecommons.org/licenses/by/ $4.0 /)$.

\begin{abstract}
Digital trading apps are evidence of developing open innovations in the financial sector. The investment industry (including banks and brokers) can greatly benefit from the utilization of digital trading applications and corresponding tools, such as smart contracts. The goal of this research paper is to examine the possibility that brokers' existing mobile apps outperform banks without mobile apps in the Russian financial sector. The efficiency of brokers is compared to banks in Russia. The results of these institutions' activities are related to the number of profitable banks, which declines as a sign of high efficiency. The paper uses methods of $t$-test, linear and polynomial regression analysis between assets (dependent variable) and the profit to assets (independent variable) in Russia. The article finds the different directions of the utilization of the discussed technology, and they all share the consequential growth after the technology's introduction. The paper also discusses the various areas of digital trading apps implementation and the future contributions for the Russian banking system and economy.
\end{abstract}

Keywords: digital trading apps; smart contracts; distributed ledgers; financial services; banks

\section{Introduction}

The market of financial services provides clients with access to taking loans, depositing funds and reserves, as well as investing into the stock market or the market of securities in general. The peculiarities of the development of this sector are individual in each country. However, it often yields beneficial results on a macroeconomic level. Subsequently, our study aims to find objective and cohesive data and results on the topic of digital trading utilization in the everyday person-to-person interactions with financial service providers.

The paper tests the hypothesis that brokers with existing mobile apps outperform banks without mobile apps in the financial sector. The methods include the analytical evaluation of the correlation of examined parameters and validity of the studied nullhypothesis [1,2]. The paper also uses methods of $t$-test and regression analysis between assets (dependent variable) and the profit to assets (independent variable) in Russia.

In the short term, brokers in developed countries are likely to benefit from distributed ledger technology in digital trading applications. However, in the medium to long term, digital trading applications have the potential to expand financial inclusion by removing the barrier to access financing in developing countries. These include the availability of financial products and services, the lack of reliable, verifiable identification systems for KYC as well as other requirements, due diligence, insufficient payment and credit 
infrastructure, incomplete secured transaction structures and collateral registries, and impact of risk reduction on international money transfers.

The main hypothesis is that the efficiency of brokers and insurance institutions compared to banks and others in Russia is related to the profit to assets among peers, which is declining as a sign of increasing efficiency. Many authors used this method to prove similar hypotheses [1,2]. Digital trading technology remains nascent even if it develops rapidly. Digital trading scalability and bandwidth issues are beginning to be successfully addressed, although the current technology standard still lags behind the levels needed to support capital markets. Replacing any major part of the capital markets system will require much larger datasets to be processed.

\section{Literature Review}

There are several examples in which the use of open innovations in digital trading apps could lead to increased access to financial resources and their availability among populations [3-6]. The incomplete structure of secured transactions and the lack of reliable asset registries (including movable asset registries) means that the lack of proof of collateral can be a major obstacle to eligibility in many countries. Only two billion people in the world have a legal, effective and public status with respect to their control over an asset. Some economists estimate the value of this "dead capital" to be USD 9.3 trillion worldwide [5-8]. Anonymity is a critical requirement for many capital markets' processes. Open innovations in cryptography technologies can go a long way in protecting anonymity. In addition, the ability, for example, of counterparties to disclose information to ensure creditworthiness is extremely difficult, preventing errors that lead to serious data breaches [9-11].

It can be said that the utilization of open innovations may increase the performance results of these institutions. Thus, it is vital to compare the analytical values of banks and brokers in order to present data on organizations utilizing open innovations and those that do not. Two regression analyses were conducted in accordance with these assumptions [12-16].

The methods should seek to be fairly similar, as this would eliminate any interferences from excess factors not being related to the object of the article. Because of this, in both cases, the assets of the corresponding financial agents were taken and analyzed. Due to limited data, especially on brokers, as they are often subsidiaries of parent organizations, the independent variable is different [17-21].

All these considerations are related to the question of the association of cryptographic identifiers with real-world identities. Some people assume that a Know Your Customer (KYC) score is the responsibility of validation nodes on the accessed network. Others represent more far-reaching changes, with identity management being a service offered independently of data validation [12,13]. In addition, there is a certain degree to which regulators are likely to require a perfect view of non-anonymized data in the ledger to exercise proper market surveillance and support anti-money laundering and terrorist financing processes [22-25].

There remains a need for coordinated oversight of asset releases and the orderly functioning of the market. As far as the custodian is concerned, the ledger could be the primary destination for asset releases [26,27]. The road to the adoption of digital trading innovations in capital markets requires overcoming several obstacles. The technology requires further development and innovation in order to be truly scalable and to agree on common standards. Sufficient investments are required to develop applications and launch implementation programs [28-31].

Russian businesses often cooperate with foreign companies. The corresponding mutual settlements often involve significant sums of money. Accelerating this process of approving payments is a definitive benefit for simplifying the activities of domestic organizations. The subsequent result will be an increase in the turnover of accounts receivable [32-35]. 
Today the Russian insurance culture is assessed as average; at the same time, its development potential is significant due to the presence of a large number of industrial enterprises and new areas of insurance for individuals. The insurance sector allows consumers to simultaneously attract investment funds and increase the safety of citizens from financial losses. The use of digital trading apps in the insurance industry makes it possible to simplify both the process of finding suitable offers and the process of managing (for the insurer and the policyholder) assets. At the same time, this technology makes it possible to reduce the risk of insurance fraud due to the direct connection of the insured assets (e.g., life, property) and the database of the insurance organization. Thus, in the context of insurance, distributed ledgers will increase the efficiency of insurance processes [36-39].

The stock market in Russia is not in great demand due to its seeming complexity, low financial literacy, and the conservatism of Russian consumers. Intensification of securities use may help achieve a balance of power between banks and the community, which can impact the activities of large enterprises [40-43].

\section{Methods}

Our research paper uses an aggregate dataset from the Bank of Russia [22] and Markswebb [23]: brokers' assets, banks' assets, insurance premia to capital, payments of insurance premia, insurance premia to gross national product (GDP), profit to assets in the sector, as well as the profit volume and losses of the banking sector (Table 1).

Table 1. Attributes of the Russian finance sector from 2012 to 2019.

\begin{tabular}{|c|c|c|c|c|c|c|c|c|c|c|c|}
\hline Year & $\begin{array}{c}\text { Banks } \\
\text { with } \\
\text { Mobile } \\
\text { Apps, \% }\end{array}$ & $\begin{array}{c}\text { Brokers } \\
\text { with } \\
\text { Mobile } \\
\text { Apps, \% }\end{array}$ & $\begin{array}{c}\text { Brokers } \\
\text { Assets, } \\
\text { Trln, } \\
\text { Rubles }\end{array}$ & $\begin{array}{c}\text { Banks } \\
\text { Assets } \\
\text { Trln, } \\
\text { Rubles }\end{array}$ & $\begin{array}{l}\text { Insurance } \\
\text { Premia to } \\
\text { Capital \% }\end{array}$ & $\begin{array}{c}\begin{array}{c}\text { Payments } \\
\text { of }\end{array} \\
\text { Insurance } \\
\text { Premia \% }\end{array}$ & $\begin{array}{c}\text { Insurance } \\
\text { Premia to } \\
\text { GDP \% }\end{array}$ & $\begin{array}{c}\text { Profitable } \\
\text { Banks } \\
\text { Share \% }\end{array}$ & $\begin{array}{c}\text { Non- } \\
\text { Profitable } \\
\text { Banks } \\
\text { Share \% }\end{array}$ & $\begin{array}{c}\text { Banking } \\
\text { System } \\
\text { Profit } \\
\text { Volume }\end{array}$ & $\begin{array}{l}\text { Banking } \\
\text { System } \\
\text { Loss } \\
\text { Volume }\end{array}$ \\
\hline 2012 & 43.5 & 75.2 & 51.65 & 41.62 & 3.7 & 46.6 & 1.1 & 94.2 & 5.8 & 1.02 & 0.01 \\
\hline 2013 & 57.9 & 80.6 & 57.97 & 49.50 & 4.1 & 46.4 & 1.2 & 90.5 & 9.5 & 1.01 & 0.02 \\
\hline 2014 & 68.6 & 85.4 & 71.36 & 57.42 & 4 & 46.6 & 1.2 & 84.9 & 15.1 & 0.85 & 0.26 \\
\hline 2015 & 75.9 & 88.4 & 78.50 & 77.65 & 4.5 & 48.2 & 1.2 & 75.4 & 24.6 & 0.74 & 0.54 \\
\hline 2016 & 81.7 & 90.5 & 127.83 & 82.99 & 5.1 & 49.8 & 1.2 & 71.4 & 28.6 & 1.29 & 0.36 \\
\hline 2017 & 86.6 & 94.1 & 143.68 & 80.06 & 5.2 & 43.3 & 1.4 & 75 & 25 & 1.56 & 0.77 \\
\hline 2018 & 87.5 & 97.7 & 151.22 & 85.19 & 6 & 40 & 1.4 & 79.3 & 20.7 & 1.92 & 0.57 \\
\hline 2019 & 90.2 & 100 & 682.24 & 94.08 & 7 & 35.2 & 1.4 & 84.4 & 15.6 & 2.2 & 0.16 \\
\hline
\end{tabular}

Source: Bank of Russia, Markswebb, authors.

Our research uses an aggregate of analysis methods in Python to evaluate the correlation of examined parameters and validity of the studied null hypothesis. With regard to the research area of the article, information on banks' and brokers' operating metrics are utilized [44,45]. The first step consists of analyzing the relationship [1-3]. This proposes a detailed insight into the efficiency of institutions' operations, as it is best for them to maximize resource turnover. In order to conduct this analysis, the log-profits and log-insurance premia are calculated using the natural logarithm for both indicators for the years spanning from 2006 to 2019.

Based on this data, with the end result of calculating the standard error of the difference, the standard deviation for both indicators is calculated using the following formula:

$$
\sigma=\sqrt{\frac{\sum_{i=1}^{n}\left(x_{i}-\bar{x}\right)^{2}}{n-1}}
$$

where $\sigma$ is the standard deviation for studied statements; $n=14$ is the number of sample values for each year from 2006 to 2019; $x_{i}$ is the log-value for each corresponding year; $\bar{x}$ is the mean of log-values for profit volume and insurance premia.

Using the standard deviation, the standard error is calculated. The corresponding equation is as follows:

$$
\left(\sigma_{\bar{x}}\right)=\frac{\sigma}{\sqrt{n}}
$$


The calculated data is aggregated and utilized in calculating the standard error of the difference:

$$
S E_{d}=\sqrt{\sigma_{\text {Prof } V}^{2}+\sigma_{\text {InsP }}^{2}}
$$

where $S E_{d}$ is the standard error of the difference; $\sigma_{P r o f V}^{2}$ is the square of the standard deviation of profit volume; $\sigma_{\text {InsP }}^{2}$ is the square of the standard deviation of insurance premium.

This method is later supported by a $t$-test and regression analysis, which helps solidify the results and make decisive conclusions. The comparison of different data ranges utilized incorporates information in the underlying involvement of open innovation in the companies [30-35]. The results are expected to indicate the lacking efficiency of banks when compared to the turnover in other financial institutions, and the conclusions should be the same in the case of all the analytical research methods. The main focus will be on the $p$-value in the case of the $t$-test and the F-test for the analysis of variance. The $t$-value is calculated using the following formula:

$$
\mathrm{t}=\frac{M_{P r o f V}-M_{\text {Ins } P}}{\frac{\sigma}{\sqrt{n}}}
$$

where $M_{P r o f V}$ is the mean value for the banks' profit volumes; $M_{\text {InsP }}$ is the mean value of the insurance premium size.

In order to further emphasize this analysis, two regression models are presented for banks and brokers with open innovations. For the former, the assets of the institutions are proposed as the dependent variable, whilst profitability is the independent variable. For the latter, assets are, similarly, the dependent variable and the number of clients is the independent variable. The intent of this further analysis is to illustrate the lacking efficiency of banks when results are compared to brokers with open innovations. As with any regression analysis, the unknown function of the estimation is expressed by the following formula:

$$
Y=f(X, \beta)+e_{i}
$$

where $Y$ is the $Y$ range of dependent variables; $X$ is the independent variable, $\beta$ and $e_{i}$ represent unknown parameters and the error terms, respectively. General view of the linear model:

$$
\hat{y}=\hat{\beta}_{0}+\hat{\beta}_{1} x_{1}+\hat{\beta} x_{2}+\hat{\beta}_{3} x_{3}+\hat{\beta}_{4} x_{y}+\varepsilon
$$

$$
\begin{gathered}
\text { Brokers }=13.594-6.708 \times \mathrm{PBS}-1.379 \times \mathrm{PV}-0.027 \times \mathrm{LV}-0.23 \times \mathrm{A}-0.34 \times \mathrm{N}-0.453 \times \mathrm{AU}-0.532 \times \mathrm{T} \\
\quad \text { Banks }=3.583-1.952 \times \mathrm{PBS}-0.298 \times \mathrm{PV}-0.012 \times \mathrm{LV}-0.17 \times \mathrm{A}-0.18 \times \mathrm{N}-0.32 \times \mathrm{AU}-0.124 \times \mathrm{T}
\end{gathered}
$$

where PBS is profitable banks with mobile apps share, PV is the profit value for banks with mobile apps, while LV is the loss value for banks with mobile apps, $\mathrm{A}$ is assets, $\mathrm{N}$ is the number of clients, AU is apps used, T is type.

One of the independent variables (number of clients) is squared in a polynomial model (quadratic model). The general specification of the polynomial model is as follows:

$$
\hat{y}=\hat{\beta}+\hat{\beta}_{1} x_{1}+\hat{\beta}_{2} x_{1}^{2}+\ldots+\hat{\beta}_{d} x_{i}^{d}+\varepsilon
$$

This follows from the linear function for each attribute:

$$
\hat{y}=\hat{\beta}_{0}+\hat{\beta}_{1} x_{1}+\varepsilon
$$

where $y$ is the growth rate of assets (banks with mobile apps and brokers with mobile apps); $x$ is the $\mathrm{n}$-dimensional vector of the growth rate, raised to the power of $d ; \beta$ is the selected coefficients; $\varepsilon$ is minimized error. 


\section{Results}

A polynomial model is created from a linear one by adding polynomial features, and the model essentially searches for the optimal linear relationship, but there are already many dimension-degrees in the feature space $d$ (degree). The number of coefficients in the model for each feature is equal to the value of the degree. Because the value does not make much sense to display, it is only important that the higher the degree, the more "flexible line" is obtained in the end.

The regression analysis is conducted with the intent of evaluating the consequential $\mathrm{R}$ square. $\mathrm{R}$ square is a measure of the goodness of fit of the regression model, which is the proportion of variation in the dependent variable explained by the independent variable(s). The share of $11.3 \%$ of banks that could not turn a profit as a consequence of the aforementioned 2009 crisis had begun to decline until 2011. However, the number of unprofitable credit organizations had been increasing until 2016, with a peak of over a quarter of banks losing money. Since then, this share has been gradually declining, but it is hard to characterize the banking sector as being stable and consistent. Figure 1 shows profits and losses for Russian banks from 2004 to 2019 [26-29].

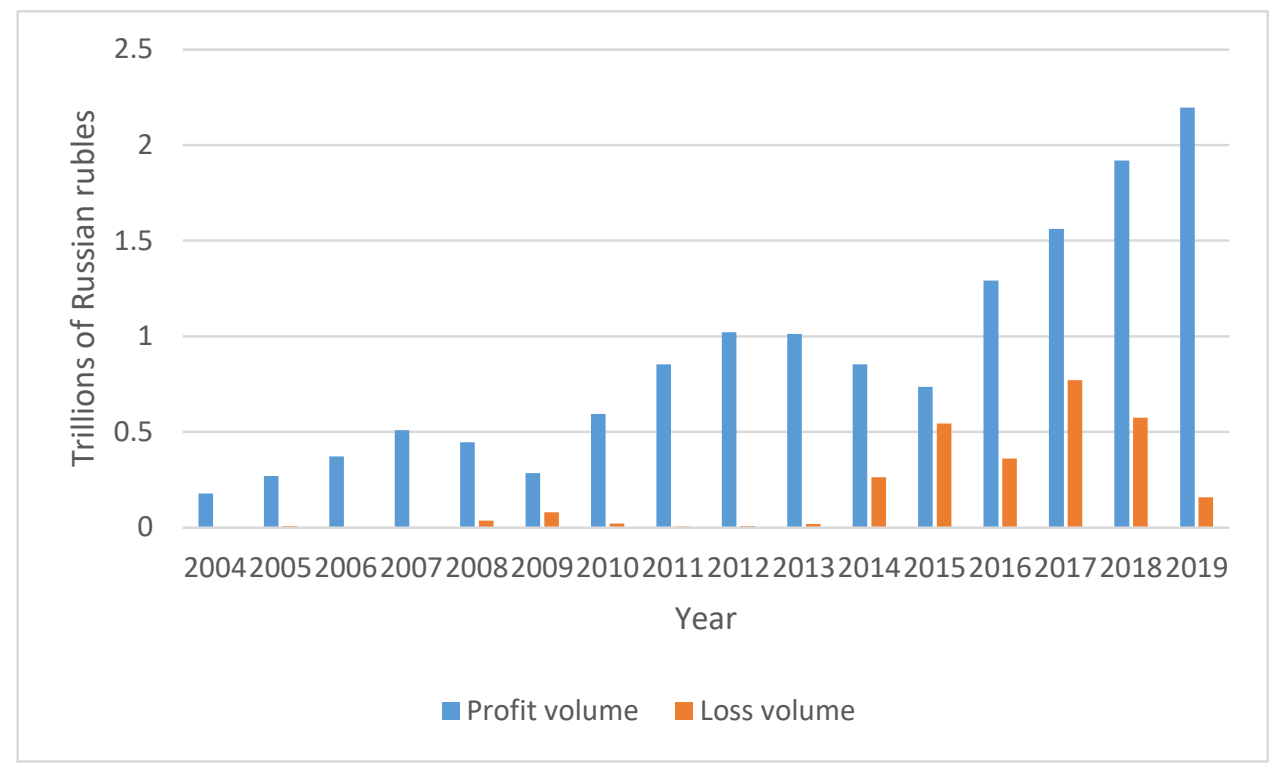

Figure 1. Profits and losses of banks without innovative mobile trading apps in 2004-2019 years.

Figure 2 reflects the dynamics of profitability of banking activities by corresponding financial institutions. It can be observed that through the years, the positive cash flow of banks has been steadily declining, leading to the emergence of companies losing money. The record-breaking highs and peaks leading to the 2008 mortgage crisis have not been restored in the last decade, signaling a shifting paradigm in Russia's banking sector. 


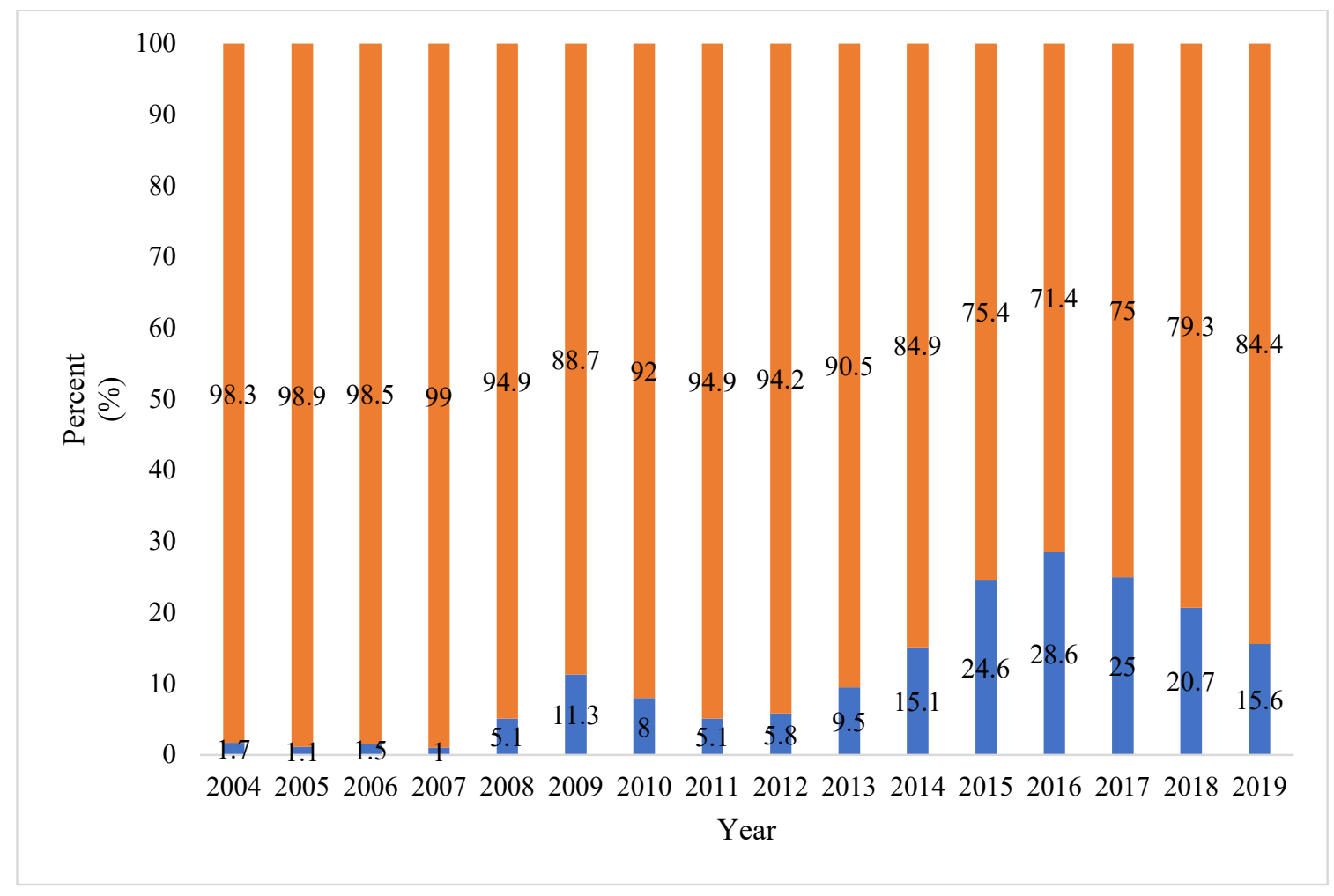

Figure 2. Share of profitable banks (orange color) without innovative mobile trading apps in 2004-2019 (\%).

Figure 3 shows the dynamics of insurance-related values from 2006 to 2019 is rising, as market share has. It can be observed that whilst the nominal value of insurance premia is rising, the share has been dropping since the financial crisis in 2010, to be specific. This allows for the prospects of digital trading implementation in sectors that are becoming increasingly more diversified.

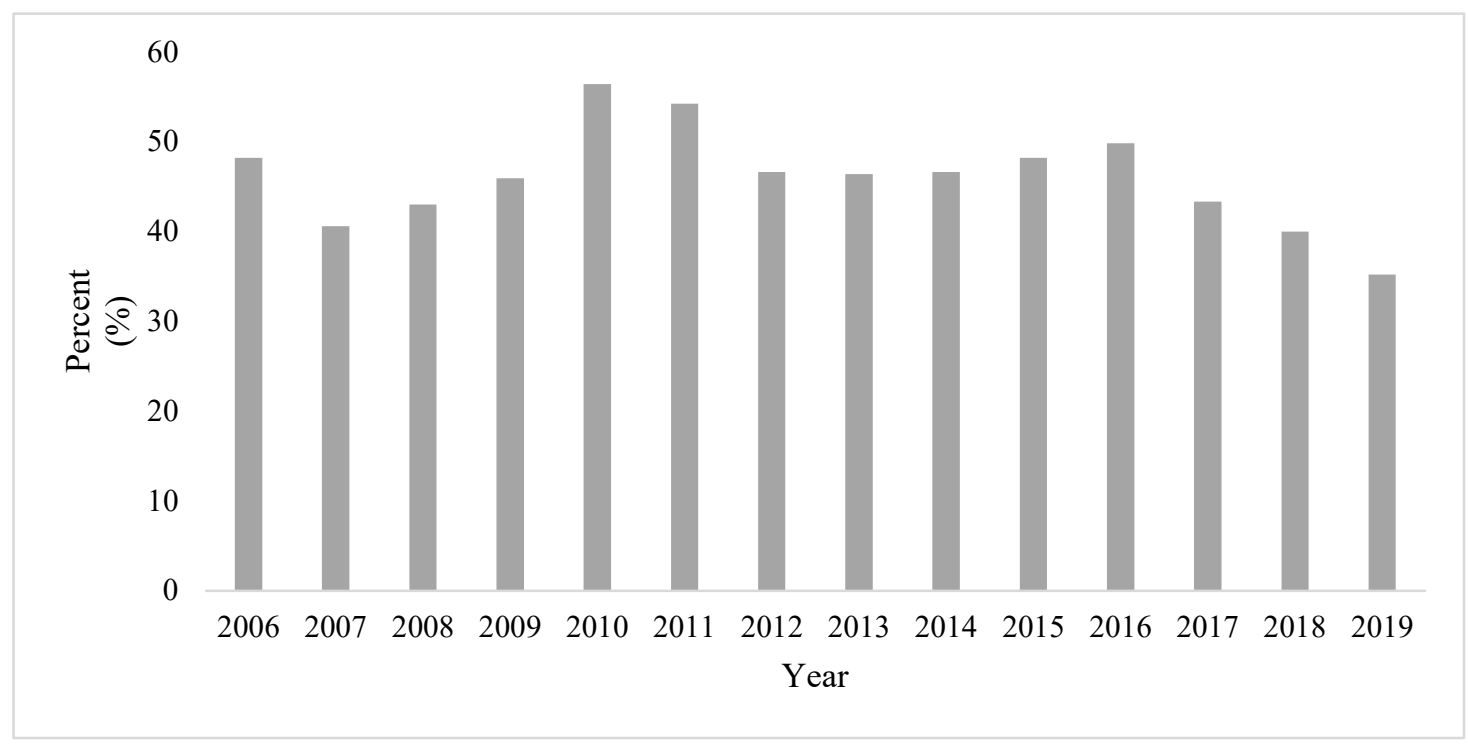

Figure 3. Main payment of insurance organizations to banks and brokers in 2006-2019.

Regarding this data, an analysis was conducted researching the indicators of insurance organizations through corresponding premiums and banks using their profits and losses. The article proposes the standard error of the difference for the two indicators-a value which, furthermore, is higher than that of the standard error for the profit volume 
and insurance premia individually, as it should be according to the research method (Tables 1-3).

Table 2. Deviation and error of the profit volume of banks and insurances premiums.

\begin{tabular}{ccccc}
\hline \multicolumn{2}{c}{ Standard Deviation } & \multicolumn{2}{c}{ Standard Error } & \multirow{2}{*}{$\begin{array}{c}\text { Standard Error of the } \\
\text { Difference }\end{array}$} \\
\cline { 1 - 4 } Prof Vol & Ins & Prof Vol & Ins & 0.200664923 \\
\hline 0.611542742 & 0.435598 & 0.163442 & 0.116418 & \\
\hline
\end{tabular}

Table 3. $t$-test analysis of profit volume and insurances premiums size.

\begin{tabular}{ccc}
\hline Parameter & $\begin{array}{c}\text { Profit Volume, Trillions of } \\
\text { Russian Rubles }\end{array}$ & $\begin{array}{c}\text { Insurance Premia, Trillions } \\
\text { of Russian Rubles }\end{array}$ \\
\hline Mean & 13.62315661 & 8.531312328 \\
Variance & 0.373984525 & 0.189745232 \\
Observations & 14 & 14 \\
Pearson Correlation & 0.869291997 & - \\
Df & 13 & - \\
$t$ Stat & 60.06924991 & - \\
$\mathrm{P}(\mathrm{T}<=\mathrm{t})$ one-tail & $1.39403 \times 10^{-17}$ & - \\
$\mathrm{P}(\mathrm{T}<=\mathrm{t})$ two-tail & $2.78806 \times 10^{-17}$ & - \\
\hline
\end{tabular}

The fact of the profit volume's standard deviation and standard error is higher than that of insurance premiums may signal uncertainty regarding this indicator for banks. The industry's subjects are strongly reliant on the macroeconomic state of the national economy as a whole. However, these results of the analysis are not enough to confidently state the comparative profitability of banks compared to brokers. The next step of the analysis, consisting of separate regression statistics for banks and brokers, is a contributing factor for the paper's conclusions. Moreover, this information can be broadened in the $t$-test, the results of which are featured below. The $p$-values, being close to zero, confirm the hypothesis, allowing more confident conclusions to be made.

Studying the results above, the $p$-values support and confirm the conclusions of Table 1. $t$-tests were run to test to see if profit volume and size of insurance premium were highly significant, which means profit volume and size of insurance premium are significantly different from each other. Expanding upon these methods, an analysis of variance was conducted regarding the asset volume of two aggregates of companies, which were picked according to their industry and market capitalization: the banking and insurance sectors.

The most significant parameters of the model are profitable banks share and profit volume. The value of non-profitable banks share is deliberately ignored in the article since it is a relative value. In general, the time series as a whole is quite strongly connected, but the data has been preprocessed and normalized.

Average absolute residual sum (AARS) can be the main indicator of model accuracy. According to many researchers, comparing profitable and non-profitable companies is an interesting approach to data analysis. They can be functionally related $y=1-x$ (Table 4 ).

For brokers, the linear relationship is not indicative, the share of errors is too high $($ AARS $=0.775)$, but it follows from the linear model of the analysis of banks that the profitability indicators of banks have the greatest impact. It is confirmed by the polynomial model since these indicators have the highest requirements for the variability of the curve and, in addition, have the highest accuracy (AARS). A distinctive feature of the banks' model was the explosive growth rate of recent years, so a more elastic nonlinear model better suits the data (Table 5). 
Table 4. Regression analysis between assets (dependent variable) and clients' dynamics (independent variable) in Russian brokers and banks with mobile apps.

\begin{tabular}{ccccc}
\hline \multirow{2}{*}{ Independent Variables } & \multicolumn{2}{c}{ Linear Model } & \multicolumn{2}{c}{ Polynomial Model } \\
\cline { 2 - 5 } & Coefficient & $\boldsymbol{p}$-Value & Coefficient & $\boldsymbol{p}$-Value \\
\hline Assets & $3.42 \times 10^{-12}$ & 0.623 & $3.42 \times 10^{-12}$ & 0.412 \\
Number of clients & $3.42 \times 10^{-12}$ & 0.587 & $3.98 \times 10^{-11}$ & 0.126 \\
Applications used & $3.98 \times 10^{-11}$ & 0.289 & $1.84 \times 10^{-7}$ & 0.325 \\
Type & $1.84 \times 10^{-17}$ & 0.231 & $7.46 \times 10^{-13}$ & 0.453 \\
Loss volume & -0.02 & -0.02 & -0.01 & 0.123 \\
Profitability & 0.06 & 0.489 & 0.07 & 0.472 \\
\hline
\end{tabular}

Table 5. Summary statistics from the regression model.

\begin{tabular}{|c|c|c|c|c|}
\hline \multirow{2}{*}{$\begin{array}{l}\text { Regression Model } \\
\text { Variables }\end{array}$} & \multirow{2}{*}{$\begin{array}{l}\text { Data Type or } \\
\text { Specification }\end{array}$} & \multirow{2}{*}{$\begin{array}{l}\text { Expected } \\
\text { Sign }\end{array}$} & \multicolumn{2}{|c|}{ Summary Statistics } \\
\hline & & & Mean & Std. Deviation \\
\hline \multicolumn{5}{|c|}{ Dependent } \\
\hline $\begin{array}{c}\text { Profitable companies } \\
\text { share }\end{array}$ & Continuous & $\mathrm{n} / \mathrm{a}$ & 0.373 & 0.109 \\
\hline \multicolumn{5}{|c|}{ Independent } \\
\hline Profit to Assets & Continuous & + & 0.021 & 1.091 \\
\hline Number of Clients & Continuous & + & 1.502 & 15.049 \\
\hline App Used & $1=$ Yes; $0=$ No & + & 1.191 & 0.444 \\
\hline Type & $1=$ Brokers $; 0=$ Banks & + & 0.150 & 10.778 \\
\hline Loss Volume & Continuous & - & -2.850 & -24.636 \\
\hline Profitability & Continuous & + & 0.093 & 0.300 \\
\hline
\end{tabular}

For banks, the trend is the same; only the rates of change in the volume of assets are not as variable, so the linear model is quite accurate (AARS $=0.023$ ). The overall result is that affects the assets of banks and brokers is the profit to assets.

Apart from the evidence from Tables 1-6, these results are necessarily linked to brokers utilizing open innovations. The analysis shows proof of brokers outperforming banks, being confirmed by the results of the analysis. The presented ideas can also be expanded upon by further research on the Russian banking sector. Data on brokers is also included in the next section.

Table 6. Top players in the financial market (brokers and banks) in Russia.

\begin{tabular}{|c|c|c|c|c|c|}
\hline Brokers and Banks & R\&D Spending & Commission Fee & Exchange & Depository Fee & Digital Trading App \\
\hline BCS Broker & 21 billion Russian rubles & $\begin{array}{c}0.1 \% \text { of the transaction } \\
\text { amount }\end{array}$ & $\begin{array}{c}\text { MICEX, SAINT } \\
\text { PETERSBURG } \\
\text { EXCHANGE, NYSE, } \\
\text { NASDAQ, LSE-IOB, } \\
\text { Xetra }\end{array}$ & Free & $\begin{array}{l}\text { My Broker, QUIK, } \\
\text { MetaTrader }\end{array}$ \\
\hline SBERBANK & $\begin{array}{l}119 \text { billion Russian } \\
\text { rubles }\end{array}$ & $0.06 \%$ of daily turnover & MICEX & Free & $\begin{array}{l}\text { QUIK, Sberbank } \\
\text { Investor app }\end{array}$ \\
\hline VTB Bank & 39 billion Russian rubles & $\begin{array}{c}0.05 \% \text { of the transaction } \\
\text { amount }\end{array}$ & $\begin{array}{l}\text { MICEX, SAINT } \\
\text { PETERSBURG } \\
\text { EXCHANGE }\end{array}$ & Free & QUIK, My Investments \\
\hline Otkrytie broker & 18 billion Russian rubles & $\begin{array}{c}0.057 \% \text { of the MICEX } \\
\text { transaction amount }\end{array}$ & $\begin{array}{c}\text { MICEX, SAINT } \\
\text { PETERSBURG } \\
\text { EXCHANGE, NYSE, } \\
\text { NASDAQ, European } \\
\text { platforms }\end{array}$ & $\begin{array}{c}\text { USD } 2 \text { per month; free } \\
\text { of charge if there were } \\
\text { no transactions }\end{array}$ & $\begin{array}{l}\text { QUIK, MetaTrader, } \\
\text { Otkritie Broker app }\end{array}$ \\
\hline FINAM broker & 13 billion Russian rubles & $\begin{array}{c}0 \% \text { when trading on } \\
\text { MICEX }\end{array}$ & $\begin{array}{c}\text { MICEX, SAINT } \\
\text { PETERSBURG } \\
\text { EXCHANGE, NYSE, } \\
\text { NASDAQ }\end{array}$ & $\begin{array}{c}\text { USD } 2 \text { per month, free } \\
\text { of charge if there were } \\
\text { no transactions }\end{array}$ & QUIK, Finam Trade app \\
\hline $\begin{array}{c}\text { TINKOFF } \\
\text { INVESTMENTS broker }\end{array}$ & 11 billion Russian rubles & $\begin{array}{c}0.3 \% \text { of the transaction } \\
\text { amount }\end{array}$ & $\begin{array}{l}\text { MICEX, SAINT } \\
\text { PETERSBURG } \\
\text { EXCHANGE }\end{array}$ & Free & Tinkoff Investments \\
\hline
\end{tabular}


Autocorrelation is also present at times, even at a significant level, but this trend is not constant and varies during the K period. As a result, we can conclude that the distortion on the internal predetermination of the series in this model is minimal. The estimated correlation is in Table A1.

Auto-regression test statistic results are necessary to reduce the probability that the selected data and the expected forecasts are simply in the same upward/downward trend but, in fact, do not depend on each other in any way. Based on the table, the data as a whole is not too strongly determined by past values. It can be argued that they are more likely to be determined by a particular model.

The complicated nature of organizations providing financial services requires automatic mechanisms of controlling liquidity in a company, especially one that offers loans to the general population, organizations, and peers. The aforementioned technological breakthroughs may possess a critical role in the further growth in the industry, as companies develop new methods of controlling operations. Figure 4 presents data on bankruptcy cases of credit organizations. The long-term growth of the indicator is correspondent to the risks of financial services, highlighting the necessity of innovation in the sector. Digital trading technologies can also play a vital role since smart contracts can be utilized for automated bankruptcy initiation processes.

45

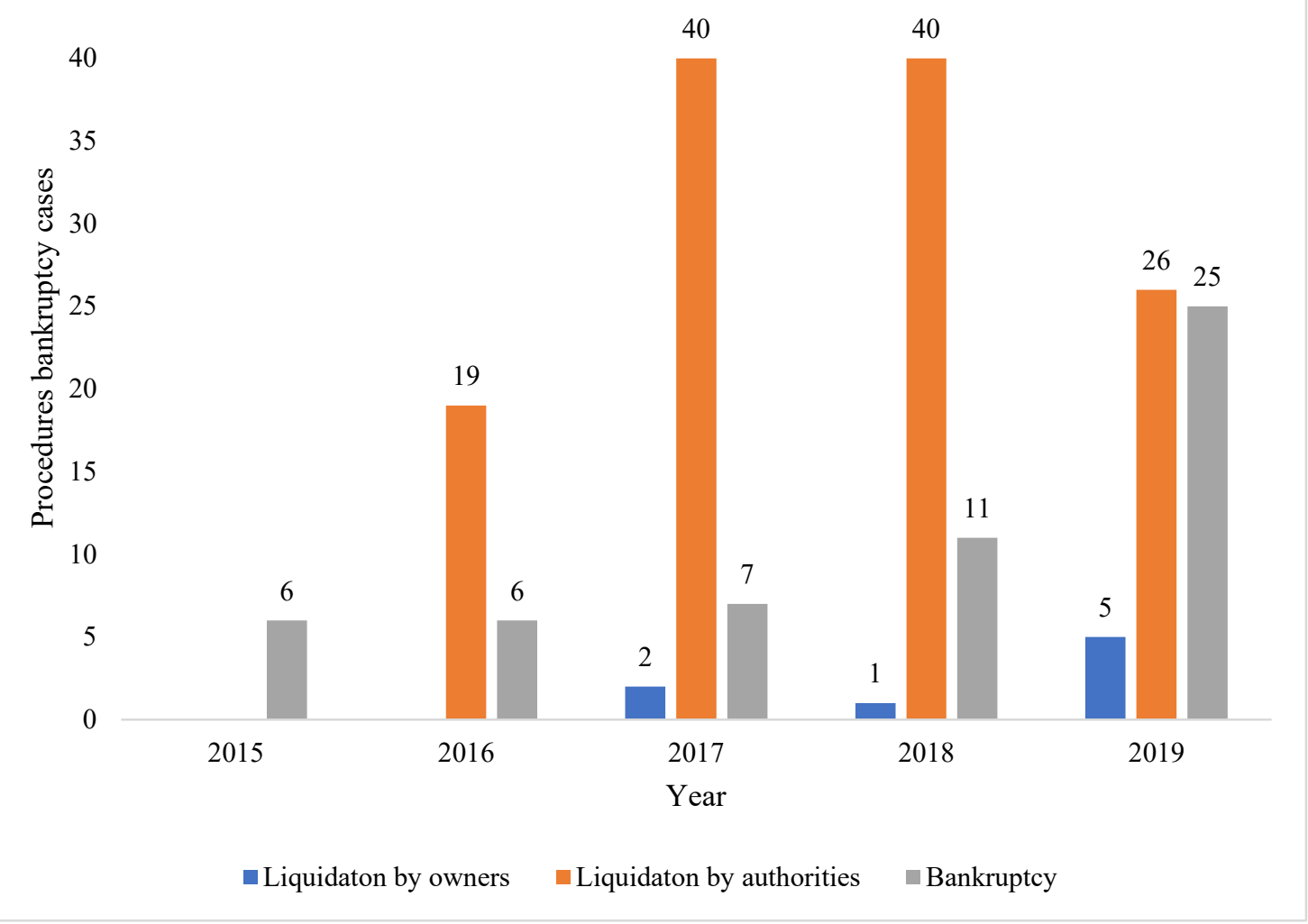

Figure 4. Procedures of bankruptcy cases in brokers and banks in 2015-2019.

The results of the case analysis observe asset allocation on the debt-weight of organizations. Figure 5 illustrates the specifics of companies providing financial services, in part their intense reliance on liabilities to generate future profits. These moments become critical in an organization's lifespan: they are often not able to comply with the conditions of the taken loans. Along with regulation from central banks that may be enforced using digital trading technologies, credit organizations strive to achieve a selfsufficient level of sustainability, as well as the opportunity to continue operations long after the company has been founded. The figure below highlights the complications of such 
thoughts. The trend of the well-being and profitability of the banking sector are shown in Appendix (Figures A1 and A2, Table A1).

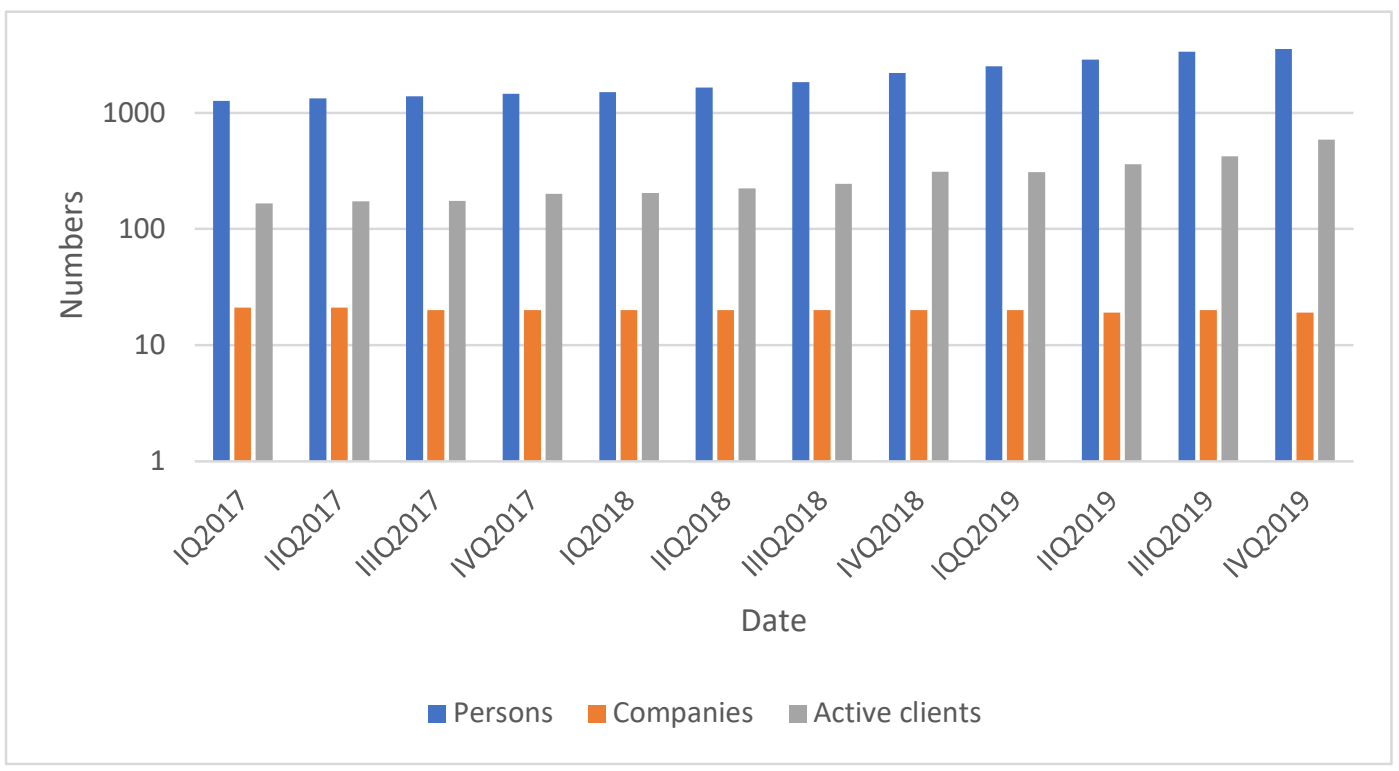

Figure 5. Clients' dynamics in open innovation brokers in 2017-2019.

The study is able to draw the following conclusions regarding it: reports from the latest years illustrate new regulation processes that may be required to further develop the banking sector, as well as to achieve sustainability in it.

Furthermore, Figure 4 expands upon the struggle that may be met in the industry. It, in turn, analyzes insurance companies, which are closely related to the credit organizations that were observed previously. It can be seen that the up-trend is also present in this subsector of financial services. Of course, as with the subject of the research paper, the interest of digital trading utilization becomes evident by the complications that meet financial service providers in different categories of products.

The market of securities has been actively developing in recent years. Figure 5 demonstrates this with the dynamics of customers on brokerage services: along with the increase of individuals using brokerage services, a growing number of active clients may become evidence of increased financial literacy of the population, as well as the growth in interest in securities and their markets. This accessibility is, of course, correlated with available technologies that must be further developed along with the financial market. As has been observed, the technologies may be used with success, simultaneously negating the risk.

\section{Summary of Brokers and Banks in Russia}

Operational risks come into play through the introduction of new open technologies, either by launching parallel infrastructures as disruptive decisions grow or through more substantial lift-and-shift migrations. A significant number of brokers and banks will require ensuring that these operational risks are minimized. The digital trading open innovation during implementation will require participants to be able to quickly recover or fall back to traditional management [46,47].

The problem of the inability of existing digital trading open innovations to be perceived as stable sources of value needs to be addressed. There are several ways to innovate in this area, but in essence, cash would be just another asset class on the ledger. Another easier way is to use existing bank accounts, where participants contribute liquidity to trade in separate accounts, with changes in the cash register reflected in their trading account balance (Table 6). 
In Russia, the top banks have greater assets (Sberbank, VTB bank) than brokers (BCS Broker, Otkrytie broker, Finam broker, Tinkoff investments broker). It was found that a strong IT budget in top banks does not mean that they are "outperforming" the brokers. This could be due to other factors, such as the initial endowment of assets. Based on the results of the study of the financial market of the Russian Federation, this paper adds the following to the underlying body of knowledge.

Firstly, the main driving forces behind the development of financial markets are globalization, securitization and disintermediation. Secondly, the main features of the Russian financial market are its relative youth, the conservatism of many consumers due to the difference in the mentality of a society with a market economy, as well as the instability of demand for insurance services and services of professional participants in the market of valuable securities due to the difficult economic situation in Russia in relation to developed countries. Each of these characteristics makes its own adjustments to the intensity of adaptation and use of various new financial technologies [48,49].

Customer-centricity and nearly ubiquitous internet access have influenced consumer expectations regarding the quality of services provided by financial institutions. There are complications for the formation of financial marketplaces. The very foundation of the financial market in the field of payments and transfers, lending, insurance and investments is changing-from looking for leadership in technology to finding leadership in innovations that will reduce costs and increase flexibility in pricing policy [50-53].

The study's results show that the nature, mechanism of application and examples of distributed ledger open innovative technology contribute to the identification of the main directions of further developments. It includes roboadvising, smart contracts, the use of digital trading apps to simplify the international money transfer system, personal lending and property management (insurance) using digital trading apps. It was found that the biggest advantages of such original innovations are increased transparency, a decrease in the likelihood of fraud, acceleration and simplification of business processes in systems using digital trading apps. However, the disadvantages that may affect the possibility of using the technology in the Russian financial market in its current state are also worth considering [54-58].

Industry alignment will be required at specific design points such as: systems being completely open (as is the case with bitcoin) or using permission-based access requirements; principles of suitability when interacting with the ledger; interoperability between different networks, which can potentially run different consensus protocols and guard against coding errors, creating unintended side effects (especially when using smart contracts) [50-52].

All of this is important to harmonize and consolidate in order to develop open, innovative systems and interoperability standards. There needs to be a clear agreement on digital trading management, which should be subsequently further improved in the case of the emergence of new exploits. This will include management processes, approval updates, roles and responsibilities.

\section{Conclusions}

Digital trading apps in the context of their use in the securities market allow using roboadvising and accessibility anywhere with the Internet to make investments-both large and small. Roboadvising allows for the reduction of operating and commercial costs, increases in the efficiency of communication with consumers and makes investments more affordable both from a moral and technological standpoint.

It is possible to use big data from digital trading apps by central banks in the context of tracking the movement of funds between the Bank of Russia and commercial banks, as well as transactions with reserves. In this case, for the regulator, the efficiency of control over compliance with requirements increases, and for credit institutions, the likelihood of overestimating the value of assets in relation to liabilities to their customers' decreases. This makes the institution of bankruptcy more effective and objective. 
The investment industry (including banks and other organizations) can greatly benefit from the utilization of digital trading applications. The brokers' existing mobile apps outperform banks without mobile apps in the financial sector. The article finds the different directions of the utilization of the discussed technology, and they all share the consequential growth after the technology's introduction. The paper also discusses the various areas of digital trading apps implementation and the future contributions for the Russian banking system and economy.

Future research can focus on reviewing different organizations' applications of the aforementioned technologies. The prospects of the open innovations of digital trading and smart contracts are yet to be completely and thoroughly researched, even though, as has been reviewed, these topics are the subject of many articles. The technical requirements and necessities for incorporating smart contracts into bankruptcy cases should be examined in-depth, as well as the utilization of foolproof security with digital trading.

Author Contributions: Conceptualization, A.L.; Data curation, K.S.; Formal analysis, A.M.; Validation, M.U.; Visualization, S.Y.; Writing-original draft, S.Y., A.L. and M.U.; Writing-review and editing, A.L., A.M., O.L., K.K. and X.T. All authors have read and agreed to the published version of the manuscript.

Funding: This research received no external funding.

Institutional Review Board Statement: Not applicable.

Informed Consent Statement: Not applicable.

Data Availability Statement: Data sharing not applicable.

Conflicts of Interest: The authors declare no conflict of interest.

\section{Appendix A}

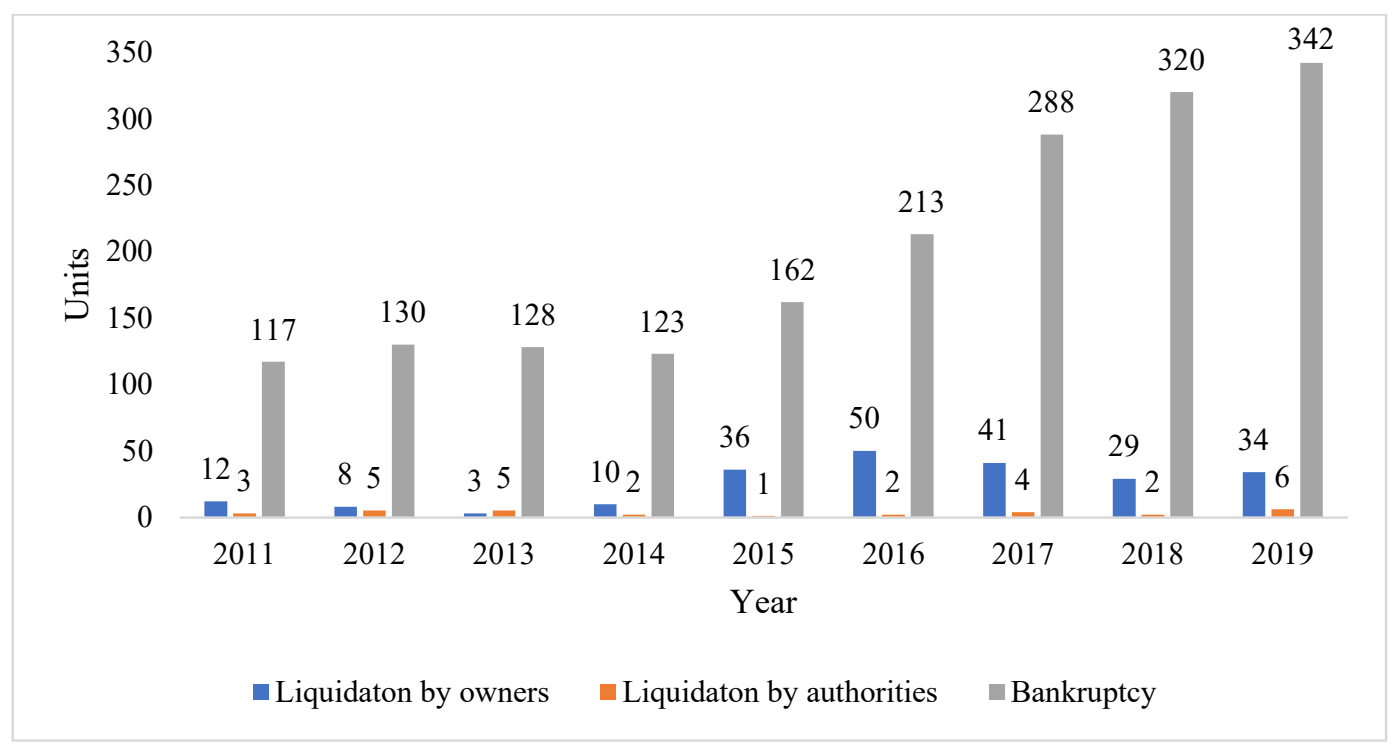

Figure A1. Structure of banks under bankruptcy procedure in 2011-2019. 


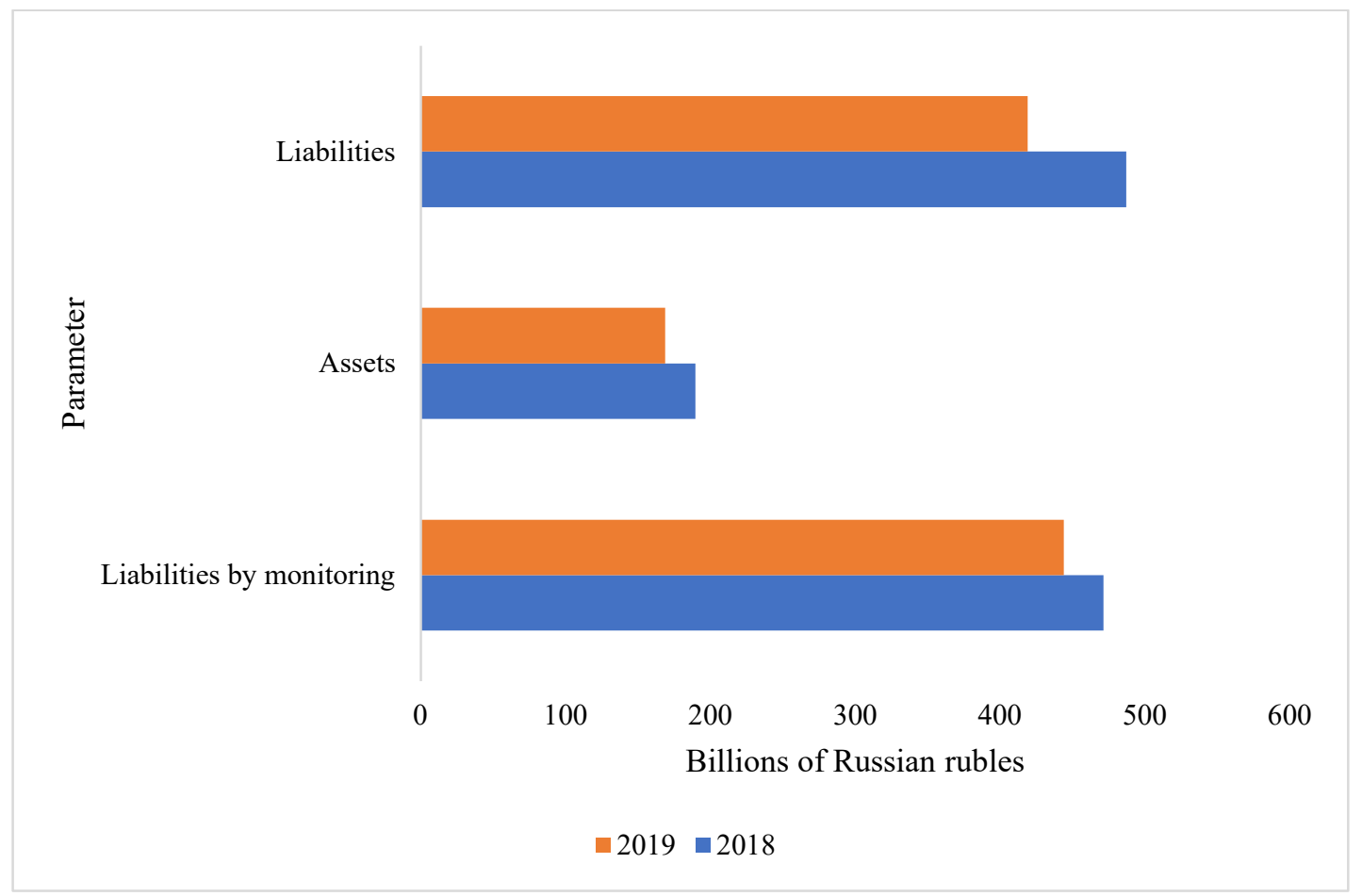

Figure A2. Banks currently proceeding in bankruptcy cases in 2018-2019.

Table A1. Estimated correlations.

\begin{tabular}{ccccccc}
\hline & \multicolumn{2}{c}{ Banks with Mobile Apps } & \multicolumn{3}{c}{ Banks without Mobile Apps } \\
\cline { 2 - 7 } NO & $\begin{array}{c}\text { Profitable Banks } \\
\text { Share \% }\end{array}$ & $\begin{array}{c}\text { Profit } \\
\text { Volume }\end{array}$ & $\begin{array}{c}\text { Loss } \\
\text { Volume }\end{array}$ & $\begin{array}{c}\text { Profitable Banks } \\
\text { Share \% }\end{array}$ & $\begin{array}{c}\text { Profit } \\
\text { Volume }\end{array}$ & $\begin{array}{c}\text { Loss } \\
\text { Volume }\end{array}$ \\
\hline 1 & 0.69 & 0.02 & -0.06 & 0.59 & 0.05 & -0.04 \\
2 & 0.01 & -0.26 & -0.16 & 0.05 & -0.15 & -0.06 \\
3 & -0.72 & -0.42 & 0.03 & -0.62 & -0.28 & 0.13 \\
4 & -0.01 & -0.14 & -0.37 & 0.07 & -0.05 & -0.25 \\
5 & -0.66 & -0.07 & -0.72 & 0.36 & -0.03 & -0.12 \\
6 & -0.47 & 0.00 & 0.15 & -0.22 & 0.01 & 0.32 \\
\hline
\end{tabular}

\section{References}

1. Ashta, A.; Herrmann, H. Artificial intelligence and fintech: An overview of opportunities and risks for banking, investments, and microfinance. Strateg. Chang. 2021, 30, 211-222. [CrossRef]

2. Tiniç, M.; Tanyeri, B.; Bodur, M. Who to trust? Reactions to analyst recommendations of domestic versus foreign brokerage houses in a developing stock market. Financ. Res. Lett. 2021, 101950. [CrossRef]

3. Yun, J.J.; Won, D.; Park, K. Entrepreneurial cyclical dynamics of open innovation. J. Evol. Econ. 2018, 28, 1151-1174. [CrossRef]

4. Yun, J.J.; Liu, Z. Micro- and Macro-Dynamics of Open Innovation with a Quadruple-Helix Model. Sustainability 2019, 11, 3301. [CrossRef]

5. Kenda, K.; Kažič, B.; Novak, E.; Mladenić, D. Streaming Data Fusion for the Internet of Things. Sensors 2019, 19, 1955. [CrossRef]

6. Kang, Q.; Zhou, H.; Kang, Y. An Asynchronous Advantage Actor-Critic Reinforcement Learning Method for Stock Selection and Portfolio Management. In Proceedings of the 2nd International Conference on Big Data Research, Seattle, WA, USA, 10-13 December 2018; pp. 141-145. [CrossRef]

7. Jiao, Y.; Jakubowicz, J. Predicting Stock Movement Direction with Machine Learning: An Extensive Study on S\&P 500 Stocks. In Proceedings of the 2017 IEEE International Conference on Big Data (IEEE BigData 2017), Boston, MA, USA, 11-14 December 2017.

8. Hope, O.K. Firm-level disclosures and the relative roles of culture and legal origin. J. Int. Financ. Manag. Account. 2003, 14, 218-248. [CrossRef]

9. Hofstede, G. Culture's Consequences: Comparing Values, Behaviors, Institutions, and Organizations across Nations; Sage Publications: Thousand Oaks, CA, USA, 2001. 
10. Hedge, M.S.; Krishna, G.; Srinath, R. An Ensemble Stock Predictor and Recommender System. In Proceedings of the IEEE 2018 International Conference on Advances in Computing, Communications and Informatics (ICACCI 2018), Bangalore, India, 19-22 September 2018.

11. Hartog, D.N.; Verburg, R.M. High performance work systems, organisational culture and firm effectiveness. Hum. Resour. Manag. J. 2004, 14, 55-78. [CrossRef]

12. Mikhaylov, A. Development of Friedrich von Hayek's Theory of Private Money and Economic Implications for Digital Currencies. Terra Econ. 2021, 19, 53-62. [CrossRef]

13. Grant, A.M.; Mayer, D.M. Good soldiers and good actors: Prosocial and impression management motives as interactive pre-dictors of affiliative citizenship behaviors. J. Appl. Psychol. 2009, 94, 900-912. [CrossRef]

14. Goldberger, A.S. The Interpretation and Estimation of Cobb-Douglas Functions. Econometrica 1968, 36, 464. [CrossRef]

15. Galbreath, J. Drivers of Corporate Social Responsibility: The Role of Formal Strategic Planning and Firm Culture. Br. J. Manag. 2010, 21, 511-525. [CrossRef]

16. Dooyum, U.D.; Mikhaylov, A.; Varyash, I. Energy security concept in Russia and South Korea. Int. J. Energy Econ. Policy 2020, 10, 102-107. [CrossRef]

17. Coyle, D. The Culture Code: The Secrets of Highly Successful Groups; Bantam: New York, NY, USA, 2018.

18. An, J.; Mikhaylov, A.; Richter, U.H. Trade war effects: Evidence from sectors of energy and resources in Africa. Heliyon 2020, 6, e05693. [CrossRef]

19. An, J.; Mikhaylov, A. Russian energy projects in South Africa. J. Energy S. Afr. 2020, 31, 58-64. [CrossRef]

20. Mikhaylov, A. Brokers and Banks; Data Archiving and Networked Services: Amsterdam, The Netherlands, 2021. [CrossRef]

21. Swidler, A. Culture in Action: Symbols and Strategies. Am. Sociol. Rev. 1986, 51, 273. [CrossRef]

22. Bank of Russia. Available online: https:/ / www.cbr.ru/eng/statistics/ (accessed on 18 June 2021).

23. Markswebb. 2021. Available online: https:/ / markswebb.ru (accessed on 18 June 2021).

24. Ouchi, W.G.; Wilkins, A.L. Organizational culture. Annu. Rev. Sociol. 1985, 11, 457-483. [CrossRef]

25. O'Rilly, C.; Chatman, J. Culture as social control: Corporations, culture, and commitment. Res. Organ. Behav. 1996, 18, 157-200.

26. Neudecker, T.; Hartenstein, H. Could network information facilitate address clustering in Bitcoin? In Proceedings of the 21st International Conference on Financial Cryptography and Data Security, Sliema, Malta, 3-7 April 2017; Springer: Cham, Germany, 2017; pp. 155-169.

27. Murphy, P.J.; Cooke, R.A.; Lopez, Y. Firm culture and performance: Intensity's effects and limits. Manag. Decis. 2013, 51, 661-679. [CrossRef]

28. Mello, J.E.; Stank, T.P. Linking firm culture and orientation to supply chain success. Int. J. Phys. Distrib. Logist. Manag. 2005, 35, 542-554. [CrossRef]

29. Marion, T.; Fixson, S. The Innovation Navigator: Transforming Your Organization in the Era of Digital Design and Collaborative Culture; University of Toronto Press: Toronto, ON, Canada, 2018.

30. Manning, C.D.; Raghavan, P.; Schütze, H. Introduction to Information Retrieval; Cambridge University Press: New York, NY, USA, 2008; p. 123.

31. Lohrmann, C.; Luukka, P. Classification of intraday S\&P500 returns with a Random Forest. Int. J. Forecast. 2018, 35. [CrossRef]

32. Lischke, M.; Fabian, B. Analyzing the Bitcoin network: The first four years. Future Internet 2016, 8, 7. [CrossRef]

33. Li, J.; Cheng, K.; Wang, S.; Morstatter, F.; Trevino, R.P.; Tang, J.; Liu, H. Feature Selection: A Data Perspective. arXiv 2016, arXiv:1601.07996. [CrossRef]

34. Lewer, J.J.; Van den Berg, H. A gravity model of immigration. Econ. Lett. 2008, 99, 164-167. [CrossRef]

35. Lee, M.; Yun, J.J.; Pyka, A.; Won, D.; Kodama, F.; Schiuma, G.; Park, H.; Jeon, J.; Park, K.; Jung, K.; et al. How to Respond to the Fourth Industrial Revolution, or the Second Information Technology Revolution? Dynamic New Combinations between Technology, Market, and Society through Open Innovation. J. Open Innov. Technol. Mark. Complex. 2018, 4, 21. [CrossRef]

36. Lahmiri, S.; Bekiros, S. Cryptocurrency forecasting with deep learning chaotic neural networks. Chaos Solitons Fractals 2019, 118, 35-40. [CrossRef]

37. Kroll, J.A.; Davey, I.C.; Felten, E.W. The economics of Bitcoin mining, or Bitcoin in the presence of adversaries. In Proceedings of the 12th Workshop on the Economics of Information Security (WEIS 2013), Washington, DC, USA, 11-12 June 2013 ; p. 11.

38. Kristoufek, L. What Are the Main Drivers of the Bitcoin Price? Evidence from Wavelet Coherence Analysis. PLoS ONE 2015, 10, e0123923. [CrossRef]

39. Kristoufek, L. BitCoin meets Google Trends and Wikipedia: Quantifying the relationship between phenomena of the Internet era. Sci. Rep. 2013, 3, 3415. [CrossRef]

40. Krauss, C.; Do, X.A.; Huck, N. Deep neural networks, gradient-boosted trees, random forests: Statistical arbitrage on the S\&P. Eur. J. Oper. Res. 2017, 259, 689-702. [CrossRef]

41. Krause, M. Bitcoin: Implications for the Developing World. Bachelor's Thesis, Claremont McKenna College, Claremont, CA, USA, 2016. Paper 1261. p. 75.

42. Koshy, D.; Koshy, P.; McDaniel, P. An analysis of anonymity in Bitcoin using p2p network traffic. In Proceedings of the 18th International Conference on Financial Cryptography and Data Security, Christ Church, Barbados, 3-7 March 2014; Springer: Berlin, Germany, 2014; pp. 469-485.

43. Kohavi, R.; John, G. Wrappers for feature selection. Artif. Intell. 1997, 97, 273-324. [CrossRef] 
44. Kenji, K.; Rendell, L. A practical approach to feature selection. In Proceedings of the 9th International Workshop on Machine Learning; Sleeman, D., Edwards, P., Eds.; Morgan Kaufmann: Burlington, MA, USA, 1992; pp. 368-377.

45. Gura, D.; Mikhaylov, A.; Glushkov, S.; Zaikov, M.; Shaikh, Z.A. Model for estimating power dissipation along the interconnect length in single on-chip topology. Evol. Intell. 2020, s12065. [CrossRef]

46. Mikhaylov, A. Pricing in Oil Market and Using Probit Model for Analysis of Stock Market Effects. Int. J. Energy Econ. Policy 2018, $8,69-73$.

47. Mikhaylov, A. Volatility Spillover Effect between Stock and Exchange Rate in Oil Exporting Countries. Int. J. Energy Econ. Policy 2018, 8, 321-326.

48. Mikhaylov, A. Oil and Gas Budget Revenues in Russia after Crisis in 2015. Int. J. Energy Econ. Policy 2019, 9, 375-380.

49. Mikhaylov, A. Cryptocurrency Market Development: Hurst Method. Financ. Theory Pract. 2020, 24, 81-91. [CrossRef]

50. Mikhaylov, A.; Moiseev, N.; Aleshin, K.; Burkhardt, T. Global climate change and greenhouse effect. Entrep. Sustain. Issues 2020, 7, 2897-2913. [CrossRef]

51. Nie, D.; Panfilova, E.; Samusenkov, V.; Mikhaylov, A. E-Learning Financing Models in Russia for Sustainable Development. Sustainability 2020, 12, 4412. [CrossRef]

52. Nyangarika, A.; Mikhaylov, A.; Tang, B.-J. Correlation of Oil Prices and Gross Domestic Product in Oil Producing Countries. Int. J. Energy Econ. Policy 2018, 8, 42-48.

53. Nyangarika, A.; Mikhaylov, A.; Richter, U. Oil Price Factors: Forecasting on the Base of Modified Auto-regressive Integrated Moving Average Model. Int. J. Energy Econ. Policy 2019, 9, 149-160.

54. Nyangarika, A.; Mikhaylov, A.; Richter, U. Influence Oil Price towards Economic Indicators in Russia. Int. J. Energy Econ. Policy 2019, 9, 123-130. [CrossRef]

55. Yumashev, A.; Ślusarczyk, B.; Kondrashev, S.; Mikhaylov, A. Global Indicators of Sustainable Development: Evaluation of the Influence of the Human Development Index on Consumption and Quality of Energy. Energies 2020, 13, 2768. [CrossRef]

56. An, J.; Mikhaylov, A.; Jung, S.-U. The Strategy of South Korea in the Global Oil Market. Energies 2020, 13, 2491. [CrossRef]

57. An, J.; Mikhaylov, A.; Kim, K. Machine Learning Approach in Heterogeneous Group of Algorithms for Transport Safety-Critical System. Appl. Sci. 2020, 10, 2670. [CrossRef]

58. An, J.; Mikhaylov, A.; Jung, S.-U. A Linear Programming Approach for Robust Network Revenue Management in the Airline Industry. J. Air Transp. Manag. 2021, 91, 101979. [CrossRef] 